\title{
THE IMPACT OF MICROFINANCE ON ENTREPRENEURSHIP IN KYRGYZSTAN ${ }^{1}$
}

\section{Kadyrbek Sultakeev, Kamalbek Karymshakov, Burulcha Sulaimanova*}

\begin{abstract}
The concept of microfinance has developed rapidly since its inception in 1976. Despite its development, the impact it has on entrepreneurship is a subject of debate. Scholarly articles have recently emerged outlining that successful entrepreneurship depends on individual and household characteristics, and on the status of the microfinance loan received. This paper investigates the impact of microfinance on entrepreneurship in Kyrgyzstan using the nationally representative household survey data for 2013. Due to the endogeneity issue, we applied the binary response model with instrumental variables. After the adjustment for endogeneity, the result indicates that access to microcredit has a significant positive impact on entrepreneurship and shows there is a significant gender difference between men and women when making the decision to become an entrepreneur. Thus, men are more likely to become an entrepreneur than women. Another interesting finding is that elderly, less educated, and married individuals are more likely to be entrepreneurs. Therefore, it can be assumed that entrepreneurship in Kyrgyzstan is mostly represented by unskilled workers, many of which are unpaid family workers and self-employed who manage small trade markets, shops, and own land in order to generate income that does not require a particular education or labour skills.
\end{abstract}

Keywords: microfinance, entrepreneurship, instrumental variable, Kyrgyzstan

JEL Classification: G21, G23, O16, C26

\section{Introduction}

Lack of access to loans in low-income countries is generally regarded as one of the main impediments to developing entrepreneurial activities. Individuals with low income or limited wealth have no access to loans from the banking system due to the absence of collateral, whereas microfinance institutions (MFI) are solving this issue by providing access to finance for all.

The terms "microcredit" and "microfinance" are often used interchangeably. Microfinance is a financial service to low-income microenterprises including microcredit, insurance, savings, money transfers, and other financial products. However, microcredit emphasises only the small credit services to low-income clients for income-generating activities (Cornfold, 2001).

1 An earlier version of this paper was presented at the International Conference on Eurasian Economies on 9-11 September 2015, Kazan, Russia.

* Kyrgyz-Turkish Manas University, Faculty of Economics and Management (kadirbek.sultakeev@manas.edu.kg; kamalbek.karymshakov@manas.edu.kg; burulcha.sulaymanova@manas.edu.kg). 
Since its existence, Kyrgyzstan's microfinance sector has achieved major milestones in its development. Kyrgyzstan was the first country in Central Asia to adopt the law "on microfinance organisations" under which MFIs can determine their own size of loans and interest rates as well as commission rates. After the adoption of this law in 2002, microcredit has become more common in the Kyrgyz market complementing the traditional banking sector. During 2002-2016, the number of MFIs increased from 18 to 204, while the cumulative loan amount has grown more than 13 times (from 1 billion KGS to 13.3 billion KGS) and the number of borrowers has increased from 80,000 to 239,416 people.

Today, Kyrgyzstan has become the leader among the former Soviet Central Asian states in using microfinance as an income-generating business through small and medium enterprises. According to the National Bank of the Kyrgyz Republic, as at June 28, 2017, the microfinance sector is comprised of 6 microfinance companies, 101 microcredit companies, and 52 microcredit agencies.

It is important to mention that according to the National Statistical Committee of the Kyrgyz Republic (NSCKR, 2015), the share of female borrowers in all regions of Kyrgyzstan is significantly larger. In $2015,62 \%$ of borrowers were women, while only $38 \%$ were men. Another significant factor is that $65 \%$ of the total population lives in rural areas. Therefore, microcredit loans are widely used for agricultural purposes, which include credits for cultivating crops and processing agricultural products by small firms or self-employed workers. Microcredit loans are also widely used for trading and catering, which are mainly represented by small enterprises and private entities in Kyrgyzstan. In 2016, the average microcredit loan was around 55,600 KGS (817 USD), which shows that microfinance institutions are commonly facilitating credits for the poorer people in the country, which comprises $25.4 \%$ of the total population (NSCKR, 2015).

Despite the fact that in the last fifteen years microfinance has demonstrated dynamic growth, its impact on the well-being of beneficiaries has not been analysed comprehensively. There were only a few studies focusing on the impact of microfinance loans on the income level of microenterprises and household welfare (Angioloni et al., 2013; Sultakeev, 2012). In general, empirical literature on microfinance mostly analysed its effect on poverty. However, one of the important social and economic implications of microfinance is the entrepreneurship of borrowers. An increase in entrepreneurial activities leads to financial sustainability and enlarges income-generating activities, which in turn minimise the further risk of falling into poverty.

This study aims to examine the impact of microfinance loans on entrepreneurship in Kyrgyzstan. This paper makes two main contributions to existing literature. First, it contributes to the current debate on whether microfinance is important for entrepreneurship in low-income countries. Second, to our best knowledge, this is the first study of a specific case conducted in Kyrgyzstan. Supported by evidence, our estimations analyse whether microfinance loans are important in terms of the probability of individuals who receive microfinance loans to own an enterprise.

Our analysis is based on the data from the nationally representative household survey data "Kyrgyz Integrated Household Survey" (KIHS) for 2013. Entrepreneurship is measured by the indicator of whether individuals own enterprises. The main explanatory variable of our interest is also measured with the discrete variable and the main empirical issues are taken into account in our estimations. First, because literature indicates 
participation in microcredit programmes may represent endogeneity and disregarding this issue may result in an overestimation of the microfinance impact (Coleman, 1999). Second, as both of our outcome (entrepreneurship) and main explanatory variables are discrete, estimation techniques should correspond to this structure of the model. To address the first problem, we use an instrumental variable approach. Our instrumental variable is the share of microcredit borrowers in total households in a given community. According to literature, such an indicator indicates the availability of funds at a community level (Bui, 2014; Khandker, 2005). On the second issue, standard implementation of the Instrumental Variable Probit (IV-Probit) model is not appropriate as it assumes the endogenous regressor to be continuous. Therefore, we apply the IV-Probit model estimation through the "conditional mixed process" (CMP) as suggested by Roodman (2011).

The paper is organised as follows: Section 2 provides a review of the empirical literature on microfinance and entrepreneurship; Section 3 includes information on data used and descriptive statistics; Section 4 describes the methodology; Section 5 discusses the estimation results and section 6 concludes.

\section{Literature Review}

Microfinance is widely recognised as a crucial tool for poverty alleviation and socioeconomic well-being. As a result, the United Nations declared 2005 as the International Year of Microcredit. The Nobel Committee awarded the 2006 Nobel Peace Prize to Muhammad Yunus and Grameen Bank, declaring that microcredit is an ever more important instrument in the fight against poverty (Ledgerwood, 1998; Karnani, 2007).

A considerable amount of literature on the impact of microfinance on enterprises has shown that participation in a microcredit programme has positive effects, thus, microcredit loans relax credit constraints, which in turn enables entrepreneurs to manage financial resources optimally and to increase business revenue, profits, and employment (see Karlan and Valdiva, 2011; Field et al., 2013; Buera et al., 2012; Kholis, 2009; Babajide, 2012; Wang, 2013).

More recently, literature has emerged that offers contradictory findings about the impact of microfinance because of the divergent effect between the positive impact, no impact and even a negative impact (Osunde and Mayowa, 2012; Angelucci, Karlan, and Zinman 2013; Ganle, Afriyie, and Segbefia 2015; Van Rooyen et al., 2012). These studies demonstrate that the impact of microfinance works differently from one situation to another and the impact depends on different factors ranging from the financial literacy, population density, financial service providers, and multiple borrowing (Armendáriz and Morduch, 2005).

Buckley (1997) uses the research undertaken at microenterprises in the informal sector of Ghana, Kenya, and Malawi. There is no single good model for the informal sector. Since microcredit has claimed more and more of the aid budget, it may not always be the best way to help the poorest. Donors and governments should know whether the poor gain more from more small loans than from healthcare, food assistance, and money.

Khandker et al. (2013) and De Mel et al. (2014), investigate the impact of access to credit on the return and growth of existing enterprises. For example, Khandker et al. (2013) tried to assess the impact of access to credit on microenterprise growth in 
Bangladesh. On the other hand, De Mel et al. (2014) assessed the impact of access to credit on microenterprise return in Sri Lanka. However, these studies only include borrowers who own enterprises. Another study by Ahmed et al. (2011), uses both the treatment and the comparison group in Bangladesh and indicate that the microfinance programme helps rural women to raise their standard of living. Women "with credit" have a much lower percentage of poverty in terms of its incidence ( $80 \%)$, intensity (28\%), and severity $(12 \%)$ compared to those "without credit". However, their analysis does not correct the selection bias.

One of the most thorough attempts to correct for selection bias and non-random programme placement in microlending is the study by Pitt and Khandker (1998), who use data from a World Bank survey of the Grameen Bank and two other group lending programmes in Bangladesh on labour supply, household expenditure, schooling and assets. They find that credit has a significant effect on the behaviour of low-income people when women are the programme participants.

Tedeschi (2008) highlights that there are several potential sources of bias in microfinance impact assessments. He uses a panel data set for Peruvian MFIs (Microfinance institutions) to check for the impact of a loan on microenterprise income while controlling these biases. This study provides evidence that those who will sooner become clients have greatly higher profits than those who will not become borrowers, suggesting that selection into the microfinance programme is a substantial problem. After checking for selection, it is clear that an average participant who borrows earns significantly more enterprise profits than one who does not borrow.

Belwal et al. (2012) state that female entrepreneurs are an example of the sizable majority of small-scale entrepreneurs in Africa and identify the contribution of microcredit to the economic development of female small-scale entrepreneurs in Addis Ababa. Based on questionnaires and interviews, this study claims the impact of microcredit and saving services on the economic development of female small-scale participants. The research emphasises financial features such as income, savings, credit, financial services, family obligations, and access to education.

Janda and Turbat (2013) show the determinants of the portfolio yield of MFIs in all Central Asian countries, specifically Kyrgyzstan, Tajikistan, Kazakhstan, Uzbekistan, Mongolia, Azerbaijan, Afghanistan, and China for the period 1998-2011. In this study, they argue that targeting female clients raises the financial results of MFIs while the efficiency of group lending or the benefit from rural lending, in contrast to the first expectations, were not proven. The main reason for this is the improvement of various governance forms of MFIs and the macroeconomic events possibly affecting the financial performance of microcredit institutions.

Chowdhury et al. (2005) examined the impact of microfinance on poverty in Bangladesh using the household-level survey. The data was obtained from 954 individuals who received microcredit from the three main MFIs in Bangladesh. A logit regression analysis was used to analyse the effectiveness of microfinance as a real income-generating tool. The logit regression analysis supported two main findings. The first set of findings indicated that there is a relationship between microcredit and poverty (objective and subjective poverty). The second set of findings shows that the impact of microcredit on poverty is particularly strong for about six years with some levelling off after that point. Dorfleitner et al. (2017) explore the social failures of microfinance institutions 
and analyse the relationship between several institution variables and social failure. They point out that microfinance companies with better measures for the quality of outreach appear to be less likely to fail socially.

Cai et al. (2016) consider the impact of microfinance on the level of income. Using a randomised control trial (RCT) in China, they found that microfinance programmes significantly raise household incomes and reduce poverty.

Bernard et al. (2017) identify the influence of micro-financial services on the entrepreneurial success of women entrepreneurs in Sri-Lanka using three microfinance services such as microcredit, microsavings, and microinsurance. Empirical research is based on a sample of 464 women receiving small loans, obtained using a stratified random sampling technique. The results show that microcredit and microsavings have a positive relationship to the entrepreneurial success of women, while microinsurance has a negative relationship.

Banerji et al. (2017) using a randomised field experiment in the case of India, indicate the impact of adult literacy and parental involvement interventions in developing children's learning. Households were assigned to the treatment group for training mothers on how to look after their children's learning at home or adult literacy (language and maths) classes or a combination of the two programmes. All three interventions had a modest impact on children's learning levels, particularly maths scores.

However, most studies point to the significance of microfinance over household welfare and Karnani (2007) argues that the best way to eradicate poverty is to create jobs and to increase worker productivity because borrowers do not have the abilities and creativity to be entrepreneurs. Even in the most developed countries, a large segment of society, approximately $90 \%$ of the labour force, are employees, not entrepreneurs. Today, South Korea, China, and Vietnam have reduced poverty with little microfinance activity. On the other hand, Bolivia, Indonesia and Bangladesh have not been as successful at reducing poverty despite the existence of microfinance.

The research study by Banerjee et al. (2017) also finds the entrepreneurial skills of borrowers to be the most important factor from the randomised evaluation of the microcredit programme in Hyderabad, India. Profits of small pre-existing businesses increased, but consumption did not significantly increase. Expenditure on durable goods increased, while expenditure on "temptation goods" declined. One reason may be that the average business run by a small entrepreneur is tiny and is difficult to expand due to the absence of elementary education and experience of managing credits.

Morduch (1998) conducted a cross-sectional survey of low-income people, some of whom are clients of Grameen Bank and some who have no access to these programmes. Participants that are eligible to borrow do not have higher consumption levels than control participants, and, their children are no more likely to be in school.

Banerjee et al. (2015) question whether improved access to credit can or cannot jump-start microenterprise growth. Using a randomised microfinance impact evaluation in urban Hyderabad, India, they show that microfinance has a lasting impact, especially for those participants who are well suited for entrepreneurship.

Attanasio et al. (2015) use a randomised field experiment in rural Mongolia to examine the effects of a female joint-liability microcredit programme on poverty. They demonstrate the positive impact of access to group loans on female entrepreneurship and household food consumption but not on total working hours or income in the household. 
A key problem with much of the literature on microcredit participation is solving the endogeneity problem. Considering the endogeneity issue, Chowdhury et al. (2016) use an instrumental variable technique (IV method) to assess the impact of access to microcredit on the entrepreneurial status of women. After adjusting for endogeneity, the analysis indicates that access to microcredit has a significantly positive impact on female entrepreneurship. It also has a significantly positive impact on male entrepreneurship. Similarly, in a study which set out to determine problems of endogeneity in the cross"Life in Kyrgyzstan" sectional data, Karymshakov et al. (2016) used the IV method in order to estimate the impact of remittance on youth labour supply in post-Soviet Kyrgyzstan.

Limited studies have been undertaken to analyse the microfinance impact in the case of Kyrgyzstan and these mostly consist of the qualitative evaluation and analysis of microfinance institutions in Kyrgyzstan (see Jeenbaeva, 2008; Temirbekova, 2012; Davlesov and Ibraev, 2014). Jeenbaeva (2008) provides an in-depth theoretical analysis of microfinance and microcredit practices in the Kyrgyz Republic and describes the best practices and success models. The proposal for the improvement of the normative and legal base of the microfinance system, feasibilities to increase the MFI fund, and the potential for the integration of microfinance and the general financial system of the country are formulated in this study.

Temirbekova (2012) investigates the problems of the microcredit industry emerging from the actions of the government and microfinance institutions. Using semi-structured interviews, online reports and other documents, this study showed that major obstacles to the effective application of microfinance in Kyrgyzstan are the inadequate legal framework, unfavourable fiscal and social policies, popularisation of the microfinance issue, over-indebtedness, absence of macroeconomic forecasting and planning for the agricultural sector, and the existence of dishonest Microfinance Institutions (MFIs).

Davlesov and Ibraev (2014) draw attention to the gap between demand and supply in the microfinance service market, which is the main challenge facing the development of the microfinance sector. The existing potential of the microfinance market is not fully used. The potential of the client base of the microfinance sector is six times larger than the number of borrowers. As a result, the main reason for the high interest rate is the excess demand for credit resources.

To our best knowledge, there are only three empirical studies on the impact of microfinance in the case of Kyrgyzstan (see Sultakeev, 2012; Sultakeev and Bayrak, 2018; and Angioloni et al., 2013).

Sultakeev (2012) investigates the effect of microcredit on microenterprise income in Kyrgyzstan. Angioloni et al. (2013) empirically assess the impact of microcredit loans on household welfare. Sultakeev and Bayrak (2018) investigate the impact of microfinance on poverty. Logit regression was used to determine the variables that affected poverty. The dependent variable is poverty (poor-1, not poor-0); independent variables are individual, family, regional and microfinance specific characteristics that influence poverty. The findings show that microfinance is associated with lower poverty; however, the impact of microcredit is not effective in the short-term although the effect of microcredit on poverty is stronger in the long run.

These three studies do not investigate the impact of microcredit on entrepreneurship; moreover, they worked with a smaller sample size and did not correct the endogeneity 
issue, which arises from microcredit programme participation. For example, the study by Sultakeev (2012), suffers from some limitations, such as the sample size of the study is small and only covers two regions of the seven regions in the country and is not nationally representative. While the paper by Angioloni et al. (2013) who evaluate the welfare effect of the impact of microfinance and the study by Sultakeev and Bayrak (2018), which examines the impact of microcredit on poverty, do not take the endogeneity problem into account.

\section{Data and descriptive statistics}

KIHS data for 2013 is used to investigate the microfinance impact on entrepreneurship in Kyrgyzstan. This survey was conducted by the National Statistical Committee of Kyrgyzstan (NSCKR, 2013) and includes a sample of 5,000 households and is representative at the national level, as well as among the urban and rural areas of the country. This survey also includes a wide range of data information on household characteristics (composition, education, child education, health etc.) and individual (education, health, labour market participation, movements etc.) characteristics.

Table 1 shows the main individual and household characteristics, such as age, gender, marital status, education level of individuals, and the residential and compositional specification of households, both for borrowers and non-borrowers from microfinance institutions. In general, only $3.02 \%$ of individuals are microcredit borrowers and there is no significant difference in the ages of both borrowers and non-borrowers, while most of the borrowers are married.

The occupational choice distribution of microcredit borrowers shows that a significant number of borrowers are employees, almost $63 \%$. However, the share of entrepreneurs borrowing microcredits is also high reaching $33 \%$ of the total of microcredit borrowers and shows that these loans can be used in facilitating income-generating activities such as expanding businesses, hiring more employees, increasing production etc.

More than half of the individual microcredit borrowers have secondary and basic education, while $31.04 \%$ have tertiary education. The share of borrowers with technical education is much less and accounts for approximately $10 \%$.

Around $70 \%$ of borrowers reside in rural areas and shows that the microcredit is primarily demanded by the rural population rather than the urban. This can be explained by the high concentration of banks and financial institutions in urban areas, which enable customers to choose credits from various types of financial organisations. In rural areas, it is mostly the microfinance institutions that provide microloans to the population.

Expenditure per capita in borrower-households is on average 8,000 soms more than in non-borrower households and the share of land ownership is higher for microcredit borrowers. The household size and composition do not significantly differ among borrower and non-borrower households. 
Table 1 | Basic characteristics of microcredit borrowers and non-borrowers

\begin{tabular}{|c|c|c|c|c|c|}
\hline & \multirow{2}{*}{ Total } & \multicolumn{2}{|c|}{$\begin{array}{c}\text { Microcredit } \\
\text { non-borrowers }\end{array}$} & \multicolumn{2}{|c|}{$\begin{array}{l}\text { Microcredit } \\
\text { borrowers }\end{array}$} \\
\hline & & Amount & $\%$ & Amount & $\%$ \\
\hline $\begin{array}{l}\text { Microcredit loan } \\
\text { (1=household borrows } \\
\text { microcredit) }\end{array}$ & 15897 & 15417 & 96.98 & 480 & 3.02 \\
\hline \multicolumn{6}{|l|}{ Individual characteristics: } \\
\hline Age & 40.0634 & 40.04683 & - & 40.56458 & - \\
\hline \multicolumn{6}{|l|}{ Marital status: } \\
\hline - Married & 11971 & 11597 & 75.22 & 374 & 77.92 \\
\hline - Single, divorced, widowed & 3926 & 3820 & 24.74 & 106 & 22.08 \\
\hline \multicolumn{6}{|l|}{ Occupational choice: } \\
\hline - Entrepreneurs & 3592 & 3438 & 22.30 & 154 & 32.08 \\
\hline - Employee & 9890 & 9592 & 62.22 & 298 & 62.08 \\
\hline - Family contributing worker & 2415 & 2387 & 15.48 & 28 & 5.83 \\
\hline \multicolumn{6}{|l|}{ Education level: } \\
\hline - Secondary, basic & 9132 & 8849 & 57.40 & 283 & 58.96 \\
\hline - Technical education & 2203 & 2155 & 13.98 & 48 & 10.00 \\
\hline - Tertiary education & 4563 & 4413 & 28.62 & 149 & 31.04 \\
\hline \multicolumn{6}{|l|}{ Household characteristics: } \\
\hline - Household size (mean) & 4.5199 & 4.5137 & - & 4.7208 & - \\
\hline - Child ratio, $0-5$ years & 0.1193 & 0.1192 & - & 0.1252 & - \\
\hline - Child ratio, 6-17 years & 0.2094 & 0.2091 & - & 0.2218 & - \\
\hline \multicolumn{6}{|l|}{ Residence: } \\
\hline - Urban & 7118 & 6967 & 45.19 & 150 & 31.25 \\
\hline - Rural & 8780 & 8450 & 54.81 & 330 & 68.75 \\
\hline $\begin{array}{l}\text { Land ownership ( } 1=\text { household } \\
\text { owns agricultural land) }\end{array}$ & 13409 & 12973 & 84.15 & 436 & 90.83 \\
\hline $\begin{array}{l}\text { Household total expenditure } \\
\text { per capita (mean, in soms) }\end{array}$ & 36067.72 & 35800.62 & - & 44646.41 & - \\
\hline $\begin{array}{l}\text { Household microcredit loan } \\
\text { (mean, in soms) }\end{array}$ & - & - & - & 18135.63 & - \\
\hline
\end{tabular}

Source: (NSCKR, 2013) 


\section{Methodology}

The probability of an individual to be an entrepreneur $\left(y_{1 i}\right)$ is estimated with a binary choice model - the Probit model - which will be conditional on receiving microcredit loan $\left(y_{2 i}\right)$, individual, household characteristics $\left(\mathrm{x}_{1 i}\right)$. The model is formally given below (Newey, 1987):

$$
\begin{aligned}
& y_{1 i}=z_{i} \delta+u_{i}, \\
& y_{2 i}=x_{i} \Pi+v_{i},
\end{aligned}
$$

where $z_{i}=\left(y_{2 i}, \mathrm{x}_{1 i}\right), x_{i}=\left(x_{1 i}, x_{2 i}\right), \delta$ and $\Pi$ are the vectors of structural and reduced-form parameters, respectively (for a detailed variable description see Table 2).

\section{Table 2 | Variable definitions}

\begin{tabular}{|c|c|}
\hline Entrepreneurship & 1 = individual is entrepreneur, $0=$ otherwise. \\
\hline \multicolumn{2}{|l|}{ Explanatory Variables } \\
\hline Microcredit loan & $1=$ household borrows microcredit, $0=$ otherwise. \\
\hline Age & Age of individual (years). \\
\hline Gender & $1=$ individual is male $; 0=$ female \\
\hline Marital status & 1 = individual is married; 0 = otherwise. \\
\hline \multicolumn{2}{|l|}{ Education category: } \\
\hline - Secondary, basic & 1 = individual has basic and secondary education; $0=$ otherwise. \\
\hline - Technical education & 1 = individual has technical education; 0 = otherwise \\
\hline - Tertiary education & $1=$ individual has tertiary education; $0=$ otherwise. \\
\hline Household size & The total number of household members. \\
\hline Child ratio & The ratio of children per household, aged between $0-5$ years. \\
\hline Expenditure per capita & The expenditure per household per capita in logarithm. \\
\hline Land ownership & $1=$ household owns agricultural land, $0=$ otherwise \\
\hline Residence & $1=$ household resides in rural area, $0=$ otherwise \\
\hline \multicolumn{2}{|c|}{ Regional dummies for household: } \\
\hline - Central region & $1=$ household resides Bishkek or Chui oblast, $0=$ otherwise. \\
\hline - North region & $1=$ household resides Naryn, Talas, Issyk-Kul oblasts, $0=$ otherwise. \\
\hline - South region & $\begin{array}{l}1=\text { household resides Jalal-Abad, Osh, Batken oblasts, Osh city, } \\
0=\text { otherwise }\end{array}$ \\
\hline Microfinance availability & $\begin{array}{l}\text { Share of households with a microfinance loan in the total household } \\
\text { number in the community. }\end{array}$ \\
\hline
\end{tabular}

\section{Dependent Variable}

Source: (NSCKR, 2013) 
However, model estimation in microfinance related research faces the endogeneity issue; due to the correlation of microcredit loans or the participation status with some household's unobserved characteristics, which are not included in the model, thus making credits endogenous. In other words, households that are borrowing a microcredit loan may have specific characteristics, which in turn may also have an impact on entrepreneurial activities. As mentioned in Coleman (1999), disregarding the selection bias or endogeneity issue in microcredit programme placement may significantly overestimate the impact of programme loans. To address this problem, we introduce an equation (2), an instrumental variable approach, which is the standard method used to manage endogeneity. This instrumental variable $\left(x_{2 i}\right)$ should obey exclusion restriction, meaning that a variable should be related to a credit loan $\left(y_{2 i}\right)$ but not related to entrepreneurship $\left(y_{1 i}\right)$. Following the literature, this study will use the availability of funds at the community level as the instrumental variable (Bui, 2014; Khandker 2005). Thus, the share of microcredit borrower households with regard to the total amount of households in the community is calculated. The rationale behind using this type of variable as an instrument for microcredit is based on the assumption that communities with greater access to microfinance loans would have more households with microfinance loans.

Since our model consists of a binary dependent variable and a binary endogenous variable (microfinance participation status), the efficient estimation technique for this case is suggested by Roodman (2011) within the "conditional mixed process" or CMP. Moreover, it is not appropriate to use the standard Instrumental Variable Probit (IV-Probit) command in STATA for discrete endogenous regressors; for this reason, the IV-Probit model is estimated in the CMP modelling method.

\section{Estimation Results}

Table 3 shows the estimation results both in coefficient and marginal effect estimates from IV-Probit CMP. The first stage results using the instrumental variable approach in the IV-Probit CMP command show that the instrumental variable is highly significant. The test for the exogeneity of the instrumented variable to the outcome variable for models estimated with the CMP command is the correlation between the disturbance terms of the first stage and the main equation, which is provided as atanhrho output. The null hypothesis for this is that microcredit participation is uncorrelated with the error term in the occupational choice equation; in our case, with entrepreneurship. Due to the rejection of the null hypothesis (see Table 3), we can conclude that microcredit participation is an endogenous variable and should be corrected for endogeneity in estimation by using the instrumental variable. As shown in the table, the instrumental variable - microfinance availability - as expected, is highly significant in explaining the microcredit loan variable. 
Table 3 | Estimation results (coefficient and marginal effect estimates)

\begin{tabular}{|c|c|c|c|}
\hline & \multicolumn{2}{|c|}{$\begin{array}{c}\text { IV-Probit CMP } \\
\text { (Coefficient estimates) }\end{array}$} & \multirow{2}{*}{$\begin{array}{c}\text { Marginal } \\
\text { effect } \\
\text { estimates } \\
\text { for second } \\
\text { stage }\end{array}$} \\
\hline & $\begin{array}{l}\text { Entrepreneurship } \\
\text { (Second stage) }\end{array}$ & $\begin{array}{l}\text { Microcredit loan } \\
\text { (First stage) }\end{array}$ & \\
\hline $\begin{array}{l}\text { Microcredit loan (1=household } \\
\text { borrows credit) }\end{array}$ & $\begin{array}{l}0.8268^{* * *} \\
(0.1809)\end{array}$ & & $\begin{array}{l}0.2254^{* * *} \\
(0.065)\end{array}$ \\
\hline \multicolumn{4}{|l|}{ Individual characteristics: } \\
\hline Age & $\begin{array}{l}0.0193^{* * *} \\
(0.0013)\end{array}$ & $\begin{array}{l}-0.0008 \\
(0.0023)\end{array}$ & $\begin{array}{l}0.0035^{\star * *} \\
(0.0002)\end{array}$ \\
\hline Gender (1=male) & $\begin{array}{l}1.1369^{* * *} \\
(0.0314)\end{array}$ & $\begin{array}{c}0.1061^{*} \\
(0.0549)\end{array}$ & $\begin{array}{l}0.1998^{* * *} \\
(0.0058)\end{array}$ \\
\hline Marital status $(1=$ married $)$ & $\begin{array}{l}0.1044^{* * *} \\
(0.0390)\end{array}$ & $\begin{array}{l}-0.1063 \\
(0.0689)\end{array}$ & $\begin{array}{l}0.0184^{* * *} \\
(0.0066)\end{array}$ \\
\hline \multicolumn{4}{|l|}{$\begin{array}{l}\text { Educational category } \\
\text { (reference: Secondary Estimation } \\
\text { results and basic education) }\end{array}$} \\
\hline Technical education & $\begin{array}{l}-0.6113^{* * *} \\
(0.0484)\end{array}$ & $\begin{array}{l}-0.2774^{* * *} \\
(0.0900)\end{array}$ & $\begin{array}{l}-0.0838^{* * *} \\
(0.0050)\end{array}$ \\
\hline Tertiary & $\begin{array}{l}-0.8081^{* * *} \\
(0.0405)\end{array}$ & $\begin{array}{l}-0.0610 \\
(0.0638)\end{array}$ & $\begin{array}{l}-0.1200^{* * *} \\
(0.0051)\end{array}$ \\
\hline \multicolumn{4}{|l|}{ Household characteristics: } \\
\hline Household size & $\begin{array}{l}-0.0256^{* * *} \\
(0.0098)\end{array}$ & $\begin{array}{l}0.0768^{* * *} \\
(0.0183)\end{array}$ & $\begin{array}{l}-0.0047^{* * *} \\
(0.0017)\end{array}$ \\
\hline Child ratio & $\begin{array}{l}0.2880^{* * *} \\
(0.1016)\end{array}$ & $\begin{array}{l}-0.2786 \\
(0.2019)\end{array}$ & $\begin{array}{l}0.0525^{* * *} \\
(0.0185)\end{array}$ \\
\hline Expenditure per capita (log) & $\begin{array}{l}-0.1983^{* * *} \\
(0.0318)\end{array}$ & $\begin{array}{l}0.4310^{* * *} \\
(0.0528)\end{array}$ & $\begin{array}{l}-0.0361^{* * *} \\
(0.0058)\end{array}$ \\
\hline Land ownership ( $1=$ owns land) & $\begin{array}{l}0.7296^{* * *} \\
(0.0802)\end{array}$ & $\begin{array}{l}0.0717 \\
(0.0946)\end{array}$ & $\begin{array}{l}0.0966^{* * *} \\
(0.0067)\end{array}$ \\
\hline Residence (1=rural) & $\begin{array}{l}1.0554^{* * *} \\
(0.0352)\end{array}$ & $\begin{array}{l}0.7369^{* * *} \\
(0.0727)\end{array}$ & $\begin{array}{l}0.1845^{* * *} \\
(0.0064)\end{array}$ \\
\hline \multicolumn{4}{|l|}{$\begin{array}{l}\text { Regional dummies } \\
\text { (reference: Central region) }\end{array}$} \\
\hline North & $\begin{array}{l}0.7179^{* * *} \\
(0.0515)\end{array}$ & $\begin{array}{l}0.9428^{* * *} \\
(0.1754)\end{array}$ & $\begin{array}{l}0.1430^{* * *} \\
(0.0110)\end{array}$ \\
\hline South & $\begin{array}{l}0.5545^{\star * *} \\
(0.0516)\end{array}$ & $\begin{array}{l}0.4130^{* *} \\
(0.1839)\end{array}$ & $\begin{array}{l}0.1075^{* * *} \\
(0.0105)\end{array}$ \\
\hline
\end{tabular}




\begin{tabular}{|c|c|c|c|}
\hline \multicolumn{4}{|l|}{ Instrumental variable: } \\
\hline Microfinance availability & - & $\begin{array}{l}0.0239^{* * *} \\
(0.0011)\end{array}$ & - \\
\hline Constant & $\begin{array}{l}-2.0255^{* * *} \\
(0.3665)\end{array}$ & $\begin{array}{l}-8.3756^{* * *} \\
(0.6443)\end{array}$ & - \\
\hline Number of observations & 15897 & & \\
\hline LR chi2 & $7428.04^{* * *}$ & & \\
\hline Log likelihood & -6921.3912 & & \\
\hline atanhrho_12 & $\begin{array}{l}-0.5819^{* * *} \\
(0.1350)\end{array}$ & & \\
\hline
\end{tabular}

Source: Authors' calculations based on data from the KIHS (NSCKR, 2013)

The findings for our main variable of interest suggest that the dummy variable for microfinance participation shows that there is a statistically significant and positive impact from microfinance participation on entrepreneurship. This means that participation in the microloan increases the probability of the individual to become an entrepreneur by $22.54 \%$. Given the other control variables, this effect is considerable and confirms our hypothesis on the importance of financial resources for entrepreneurial activities.

The estimated coefficients of explanatory variables demonstrate anticipated signs. The results show that statistically, significant gender differences exist among men and women when making the decision to be an entrepreneur. Thus, men are more likely to pursue entrepreneurship roles with respect to women at $19.98 \%$. The likely reason is that most women do not use microcredit loans to start their own microenterprises as women are responsible for producing household goods and male time is a poor substitute for female time when producing these goods. Women lack the availability of required time after producing household goods to start microenterprises of their own. This confirms previous findings by Chowdhury et al. (2016) and Goetz and Gupta (1998). Similarly, Chowdhury et al. (2016) found in Bangladesh that access to microcredit has a higher marginal positive effect on male entrepreneurship than female entrepreneurship. Likewise, Goetz and Gupta (1998) and White (1991) found that loans taken by women are not used for the women's own productive activities.

Another important finding is that individuals with more education are less likely to become entrepreneurs. This could be explained by labour market specification in Kyrgyzstan, own-account workers or entrepreneurs mostly maintain and manage small trade markets and shops, which do not require particular educational or labour skills. Along with these characteristics in Kyrgyzstan, most of the individuals with land ownership are considered as own-account workers. This means that even if individuals are not employed in any other sectors, but only work as a family unpaid agriculture worker with low productivity, they are still considered to be an own-account worker. 
The dummy variable showing ownership of land by household has a positive and significant effect on the entrepreneurship decision of an individual. This shows that individuals in households with agricultural land are more likely to be an entrepreneur than those who are in households without agricultural land.

With the increase of age, the probability of becoming entrepreneurs increases insignificantly. In other words, the entrepreneurial status of an individual is positively related to their age, which may indicate that an older individual acquires more experience in the labour market and makes the decision to own their own enterprise. The same can be concluded for the marital status of an individual and although the probability is not high, married individuals are more likely to be entrepreneurs compared to their unmarried counterparts.

The location of a household has an impact on the decision of an individual to become an entrepreneur. Thus, individuals residing in a rural household at $18.45 \%$ are more likely to become entrepreneurs than those residing in urban areas. Moreover, regional differences in entrepreneurship can be observed. The estimation results show that individuals from northern and southern regions are more likely to become entrepreneurs compared to those who reside in Bishkek city or Chui oblast at $14.30 \%$ and $10.75 \%$ respectively. This observation shows that individuals from the central region are more likely to be wage paid workers. However, these regional differences in entrepreneurial activities should be interpreted with some caution. Because of the data limitations, we do not distinguish between necessity and opportunity entrepreneurship. In our study, own-account workers are considered as self-employed and entrepreneurs and the dominant part of own-account workers are vulnerable to social and economic conditions and may not represent sustainable employment. Therefore, most of the entrepreneurs may represent necessity entrepreneurs. However, those with the opportunity to find more stable employment, wage employment, may prefer this choice. This fact can be used as an argument to explain the difference between the capital city and other regions. Bishkek and the Chuy region are central for the economic activities of the country and can provide better employment options with waged employment, while comparatively less developed regions of the country cannot demonstrate large opportunities within wage employment.

\section{Conclusion}

Using the KIHS data for 2013, the present study analysed the impact of microfinance on entrepreneurship. For the purpose of this study, a binary dependent IV-Probit model is estimated. Entrepreneurship is observed only if an individual owns an enterprise. The probability of an individual to be an entrepreneur is conditional on explanatory variables, such as microcredit participation and other individual and household characteristics. Estimation results show that participation in a microloan increases the probability of the individual to become an entrepreneur, showing that, in general, widespread microcredit loans in Kyrgyzstan have a positive effect on entrepreneurial activity. The results of the individual and household level characteristics show that the decision to become an entrepreneur is highly dependent not only on individual characteristics, but also on household characteristics, such as location, composition, and wealth. 
There is a significant gender difference between men and women when making the decision to become an entrepreneur and thus, men are more likely to become entrepreneurs than women. A major finding is that elderly, less educated, and married individuals are more likely to become entrepreneurs. This finding shows that in Kyrgyzstan entrepreneurship is mostly represented by unskilled workers, which may be conditional on the fact that owning enterprise in Kyrgyzstan is usually in terms of managing small trade markets, shops, and owning land to generate income which does not require particular educational or labour skills.

The findings raise important issues for policy goals because entrepreneurship in Kyrgyzstan is mostly presented by micro-enterprises who mostly reside in rural areas and that microcredit currently is an important instrument in facilitating financial access in non-urban areas where financial institutions are not widespread. The results indicate that microcredit has a positive effect on entrepreneurship. However, the microfinance institutions are not achieving their objectives and the existing methodology of giving microcredit is not working properly. There is need to emphasise the importance of redesigning the current methodology of giving microcredit to enable women to become entrepreneurs and business training courses for unskilled workers.

A final point is that our study contributes to the growing literature on the role of the impact of microfinance on the development of entrepreneurship by using a binary dependent IV-Probit model.

Further work needs to be undertaken to answer the question of why the present form of microcredit is not working for female entrepreneurship and why elderly and less educated people are more likely to become entrepreneurs.

\section{References}

Osunde, C. and Mayowa, A. G. (2012). Microfinance and Entrepreneurial Development in Nigeria. Journal of Research in National Development, 10(3), pp. 405-410.

Ahmed, F., Siwar, C., Idris, N. A. H. and Begum, R. A. (2011). Microcredit's Contribution to the Socio-economic Development amongst Rural Women: A Case Study of Panchagarh District in Bangladesh. African Journal of Business Management, 5(22), pp. 9760-9769.

Angelucci, M., Karlan, D. and Zinman, J. (2013). Win Some Lose Some? Evidence from a Randomized Microcredit Program Placement Experiment by Compartamos Banco. SSRN Electronic Journal, 7(1), https://doi.org/10.2139/ssrn.2274284

Angioloni, S., Kudabaev, Z., Ames, G. C. and Wetzstein, M. E. (2013). Microcredit Impact in Kyrgyzstan: A Case Study. In: 2013 Annual Meeting of Southern Agricultural Economics Association. [online] Orlando: SAEA, pp. 1-39. Available at: http://ageconsearch.umn.edu/record/143838 [Accessed 19 Feb. 2018].

Armendariz, B. and Morduch, J. (2005). The Economics of Microfinance. Cambridge: Massachusetts Institute of Technology.

Attanasio, O., Augsburg, B., De Haas, R., Fitzsimons, E. and Harmgart, H. (2015). The Impacts of Microfinance: Evidence from Joint-liability Lending in Mongolia. American Economic Journal: Applied Economics, 7(1), pp. 90-122, https://doi.org/10.1257/app.20130489

Babajide, A. A (2012). Effects of Microfinance on Micro and Small Enterprises (MSEs) Growth in Nigeria. Asian Economic and Financial Review, 2(3), pp. 463-477. 
Banerjee, A., Breza, E., Duflo, E. and Kinnan, C. (2017). Do Credit Constraints Limit Entrepreneurship? Heterogeneity in the Returns to Microfinance. Buffett Institute Global Poverty Research Lab Working Paper No. 17-104, https://doi.org/10.2139/ssrn.3126359

Banerjee, A., Duflo, E., Glennerster, R. and Kinnan, C. (2015). The Miracle of Microfinance? Evidence from a Randomized Evaluation. American Economic Journal: Applied Economics, 7(1), pp. 22-53, https://doi.org/10.1257/app.20130533

Banerji, R., Berry, J. and Shotland, M. (2017). The Impact of Maternal Literacy and Participation Programs: Evidence from a Randomized Evaluation in India. American Economic Journal: Applied Economics, 9(4), pp. 303-337, https://doi.org/10.1257/app.20150390

Belwal, R., Tamiru, M. and Singh, G. (2012). Microfinance and Sustained Economic Improvement: Women Small-scale Entrepreneurs in Ethiopia. Journal of International Development, 24, pp. S84-S99, https://doi.org/10.1002/jid.1782

Bernard, D. K., Kevin, L. L. T. and Khin, A. A. (2017). Influence of Microfinance Services on Entrepreneurial Success of Women in Sri Lanka. African Journal of Business Management, 11(14), pp. 337-346, https://doi.org/10.5897/AJBM2017.8344

Buckley, G. (1997). Microfinance in Africa: Is It Either the Problem or the Solution? World Development, 25(7), pp. 1081-1093, https://doi.org/10.1016/S0305-750X(97)00022-3

Buera, F. J., Kaboski, J. P. and Shin, Y. (2012). The Macroeconomics of Microfinance. RB of St. Louis Working Paper No. 2013-034A, https://doi. org/10.3386/w17905

Bui, L. T. (2014). Microfinance and Poverty Alleviation: Does Credit Access Contribute to Reduce Household Poverty in Vietnam? [online]. MA. Georgetown University, Washington, DC. Available at: https://repository.library.georgetown.edu/handle/10822/709890 [Accessed 8 Feb. 2018].

Cai, S., Park, A. and Wang, S. (2016). Microfinance Can Raise Incomes: Evidence from a Randomized Control Trial in China. [online] Available at: https://editorialexpress.com/cgi-bin/conference/download.cgi?db_name=RESConf2017\& paper_id=103 [Accessed 8 Feb. 2018].

Chowdhury, M., Amin, S. and Farah, T. (2016). Access to Microcredit and Women's Entrepreneurship: Evidence from Bangladesh. PEP Working Paper Series No. 2016-13, https://doi.org/10.2139/ssrn.3167252

Chowdhury, M. J. A., Ghosh, D. and Wright, R. E. (2005). The Impact of Micro-credit on Poverty: Evidence from Bangladesh. Progress in Development Studies, 5(4), pp. 298-309, https://doi.org/10.1191/1464993405ps116oa

Coleman, B. E. (1999). The Impact of Group Lending in Northeast Thailand. Journal of Development Economics, 60(1), pp. 105-141, https://doi.org/10.1016/S0304-3878(99)00038-3

Cornford, R. A. (2001). Microcredit, Microfinance or Access to Financial Services: What Do Pacific People Need? [online] Foundation for Development Cooperation. Available at: http://unpan1.un.org/intradoc/groups/public/documents/APCITY/UNPAN006911.pdf [Accessed 8 Feb. 2018].

Davlesov, A. and Ibraev, N. (2014). Роль микрофинансового рынка в Кыргызской Республике: перспективы и угрозы [Role of the Microfinance Market in the Kyrgyz Republic: Perspectives and Threats]. Report of National Institute for Strategic Studies of the Kyrgyz Republic.

De Mel, S., McKenzie, D. and Woodruff, C. (2014). Business Training and Female Enterprise Startup, Growth, and Dynamics: Experimental Evidence from Sri Lanka. Journal of Development Economics, 106, pp. 199-210, https://doi.org/10.1016/j.jdeveco.2013.09.005 
Dorfleitner, G., Priberny, C. and Röhe, M. (2017). Why Do Microfinance Institutions Fail Socially? A Global Empirical Examination. Finance Research Letters, 22, pp. 81-89, https://doi.org/10.1016/j.frl.2016.12.027

Field, E., Pande, R., Papp, J. and Rigol, N. (2013). Does the Classic Microfinance Model Discourage Entrepreneurship among the Poor? Experimental Evidence from India. American Economic Review, 103(6), pp. 2196-2226, https://doi.org/10.1257/aer.103.6.2196

Ganle, J. K., Afriyie, K. and Segbefia, A. Y. (2015). Microcredit: Empowerment and Disempowerment of Rural Women in Ghana. World Development, 66, pp. 335-345, https://doi.org/10.1016/j.worlddev.2014.08.027

Goetz, A. M. and Gupta, R. S. (1996). Who Takes the Credit? Gender, Power, and Control over Loan Use in Rural Credit programs in Bangladesh. World Development, 24(1), pp. 45-63, https://doi.org/10.1016/0305-750X(95)00124-U

Janda, K. and Turbat, B. (2013). Factors Influencing Portfolio Yield of Microfinance Institutions in Central Asia. [online] MPRA Paper No. 49549. Available at: https://mpra.ub.uni-muenchen.de/49549/ [Accessed 10 Feb. 2018].

Jeenbaeva, B. (2008). Microfinance and Microcredit Development Problems in a Transition Period (Experience of the Kyrgyz Republic). PhD. National Academy of Sciences of the Kyrgyz Republic, Bishkek.

Karlan, D. and Valdivia, M. (2011). Teaching Entrepreneurship: Impact of Business Training on Microfinance Clients and Institutions. Review of Economics and Statistics, 93(2), pp. 510-527, https://doi.org/10.1162/REST_a_00074

Karnani, A. (2007). Microfinance Misses its Mark. Stanford Social Innovation Review. [online] Available at: https://ssir.org/articles/entry/microfinance_misses_its_mark [Accessed 8 Feb. 2018].

Karymshakov, K., Abdieva, R., Sulaimanova, B. and Sultakeev, K. (2016). Remittances Impact on Youth Labour Supply: Evidence from Kyrgyzstan. [online] PMMA Working Paper No. 12594. Available at: https://www.pep-net.org/sites/pep-net.org/files/typo3doc/pdf/files_ events/2015_kenya_conf/PMMA_12594.pdf [Accessed 10 Feb. 2018].

Khandker, S. R. (2005). Microfinance and Poverty: Evidence Using Panel Data from Bangladesh. The World Bank Economic Review, 19(2), pp. 263-286, https://doi.org/10.1093/wber/lhi008

Khandker, S., Samad, H. A. and Ali, R. (2013). Does Access to Finance Matter in Microenterprise Growth? Evidence from Bangladesh. [online] World Bank Policy Research Working Paper No. 6333. Available at: https://openknowledge.worldbank.org/handle/10986/12156 [Accessed 10 Feb. 2018].

Kholis, N. (2009). The Contribution of Islamic Microfinance Institution in Increasing Social Welfare in Indonesia (A Case Study of Bmt's Role at Pakem Market Micro Traders Yogyakarta). International Seminar on Islamic Financial Engineering.

Ledgerwood, J. (1998). Microfinance Handbook: An Institutional and Financial Perspective. Washington, DC: World Bank.

Morduch, J. (1998). Does Microfinance Really Help the Poor? New Evidence from Flagship Programs in Bangladesh. Research Program in Development Studies, Working Papers 198. Woodrow School of Public and International Affairs.

NSCKR (National Statistical Committee of Kyrgyz Republic), (2013). Kyrgyz Integrated Household Survey [online]. Available at: http://catalog.ihsn.org/index.php/catalog/6718/data_dictionary [Accessed 15 Feb. 2018].

NSCKR, (2015). Express Information on Microcredit of the Population by Non-Bank Financial and Credit Institutions in 2013-2015 [online]. Available at: http://stat.kg/ru/statistics/finansy/ [Accessed 10 Feb. 2018]. 
Newey, W. K. (1987). Efficient Estimation of Limited Dependent Variable Models with Endogenous Explanatory Variables. Journal of Econometrics, 36(3), pp. 231-250, https://doi.org/10.1016/0304-4076(87)90001-7

Pitt, M. M. and Khandker, S. R. (1998). The Impact of Group-based Credit Programs on Poor Households in Bangladesh: Does the Gender of Participants Matter? Journal of Political Economy, 106(5), pp. 958-996, https://doi.org/10.1086/250037

Roodman, D. (2011). Fitting Fully Observed Recursive Mixed-Process Models with CMP. Stata Journal, 11(2), pp. 159-206.

Sultakeev, K. and Metin B. (2018). Mikro finans uygulamasinin yoksulluk üzerindeki etkisi: Kirgizistan örneği [The Impact of Microfinance on Poverty: Evidence from Kyrgyzstan]. MANAS Journal of Social Studies, 7(1), pp. 255-266.

Sultakeev, K. (2012). Kırgızistan'da Yoksulluğu Önlemede Mikrokredi Uygulamaları [Microcredit Practice and Poverty Alleviation in Kyrgyzstan]. MA. Kyrgyz-Turkish Manas University, Bishkek.

Tedeschi, G. A. (2008). Overcoming Selection Bias in Microcredit Impact Assessments: A Case Study in Peru. The Journal of Development Studies, 44(4), pp. 504-518, https://doi.org/10.1080/00220380801980822

Temirbekova, N. (2012). Microfinance in Kyrgyzstan: Facilitating Women's Economic Empowerment. MA. Central European University, Budapest.

Van Rooyen, C., Stewart, R. and De Wet, T. (2012). The Impact of Microfinance in Sub-Saharan Africa: A Systematic Review of the Evidence. World Development, 40(11), pp. 2249-2262, https://doi.org/10.1016/j.worlddev.2012.03.012

Wang, X. (2013). The Impact of Microfinance on the Development of Small and Medium Enterprises: The Case of Taizhou, China. Baltimore, MD: The Johns Hopkins University.

White, S. (1991). Evaluating the Impact of NGOs in Rural Poverty Alleviation: Bangladesh Country Study. [online] Overseas Development Institute Working Paper no. 50. Available at: https://www.odi.org/sites/odi.org.uk/files/odi-assets/publications-opinion-files/6939. pdf [Accessed 7 Feb. 2018]. 